\title{
First Record of Mountain Lions, Puma concolor, in Elk Island National Park, Alberta
}

\author{
GlynNis A. HoOd and Tim NeufELd
}

Elk Island National Park, R.R. \#1, Site 4, Fort Saskatchewan, Alberta T8L 2N7 Canada, e-mail: [Hood] glynnis.hood@pc.gc.ca

Hood, Glynnis A., and Tim Neufeld. 2004. First record of Mountain Lions, Puma concolor, in Elk Island National Park, Alberta. Canadian Field Naturalist 118(4): 605-607.

Several sightings of Mountain Lions (Puma concolor) and wildlife mortalities consistent with predation by Mountain Lion have occurred in and adjacent to Elk Island National Park from February 2003 to present. These are the first recorded Mountain Lions (locally called Cougar) sightings since the area encompassing the park was protected in 1906.

Key Words: Mountain Lion, Cougar, Puma, Panther, Catamount, Puma concolor, Elk Island National Park, Alberta, range, first record.

Along with its current range, Mountain Lion (Puma concolor) historically occupied central and eastern Canada (Banfield 1974). In present day Alberta however, Mountain Lion (locally called Cougar) populations are mainly concentrated in the Rocky Mountains and the foothills (Soper 1964; Banfield 1974; Smith 1993; Pattie and Fisher 1999). By 1961, Bird described many large predators, including the Mountain Lion, as being extirpated from the aspen parkland of Canada's prairie provinces. Soper (1964) referenced individual reports of Mountain Lions north of Edmonton, Alberta at Boiler and Grand Rapids on the Athabasca River and in the Peace River Region in northwestern Alberta. $\mathrm{He}$ also noted occasional sightings in southern Alberta along the Milk, Bow, and South Saskatchewan River systems, as well as in the Cypress Hills. Smith (1993) added additional sightings near the towns of Whitecourt and Athabasca, Alberta.

Sightings of Mountain Lions are increasing in areas where they were previously unreported. Occasional sightings have been documented to the north in Wood Buffalo National Park (Gau et al. 2001), and to the south and west of Elk Island National Park (EINP) near Cooking Lake, Pigeon Lake, and Sherwood Park (Smith 1979). However, until 2003, there had never been a documented Mountain Lion sighting in EINP (Soper 1940*; Soper 1951; Burns and Cool 1984*; Parks Canada Warden Service unpublished notes). Elk Island lies between longitude W112 ${ }^{\circ} 57^{\prime} 00^{\prime \prime}$ and W112 ${ }^{\circ} 46^{\prime} 45^{\prime \prime}$ and latitude N53 ${ }^{\circ} 42^{\prime} 57^{\prime \prime}$ and N53 $3^{\circ} 0^{\prime} 37^{\prime \prime}$ (Figure 1) and covers an area of $196 \mathrm{~km}^{2}$. The park is located in the Aspen Parkland Natural Subregion (Achuff 1994) in the Beaver Hills of east-central Alberta and is home to several species of large ungulates.

Given the known distances that Mountain Lions would have to travel to access the park, Burns and Cool (1984) predicted "occurrences of cougar in Elk Island National Park [EINP] in future remain a slim possibility". The closest source populations to EINP are in the Rocky Mountains foothills and the Swan Hills region of north-central Alberta (Pattie and Fisher 1999). These populations are approximately $200 \mathrm{~km}$ away from EINP, which is well within the $500 \mathrm{~km}$ dispersal distance observed for Mountain Lions (Logan and Sweanor 1999).

On 8 February 2003 at 11:00 h one of us observed an adult Mountain Lion approximately $10 \mathrm{~km}$ south of the boundary of EINP at Islet Lake in the southern reaches of the Cooking Lake - Blackfoot Grazing, Wildlife and Provincial Recreation Area (Figure 2). In late March, a conservation officer found tracks of one large Mountain Lion and a much smaller Mountain Lion together near the northern boundary of the Provincial Recreation Area - an area that bounds the southern extent of EINP. On 26 July 2003 at 14:00 h a group of Young Canada Works students working in the park reported seeing an adult Mountain Lion just south of Highway 16 in the southern half of EINP.

An adult Mountain Lion was also seen by park visitors on two different occasions in the northcentral section of the park on 29 July 2003. The first visitor reported seeing a Mountain Lion at 07:30 h beside the main road through the park and a second visitor saw a Mountain Lion while on a nearby trail at 21:40 h. In the latter case the visitor reported seeing the Mountain Lion watching a herd of Bison (Bison bison) approximately $5 \mathrm{~km}$ from the trailhead. Equestrians saw two Mountain Lions together in the north central part of the Provincial Recreation Area around the same time.

Further sightings were reported in the fall of 2003 when a park visitor observed an adult Mountain Lion while hiking on 17 September. Another park visitor reported seeing a Mountain Lion cross the main park road on 2 October. In mid-October, a hiker reported seeing a Mountain Lion at the southern part of the Provincial Recreation Area between Push Lake and Islet Lake. On 20 November 2003 a park warden reported seeing a Mountain Lion crossing a secondary road in the east-central part of EINP.

In 2004, a cyclist observed a Mountain Lion sitting beside the main road in the northern part of the park (13 July). The most recent confirmed sighting in the park was on 24 October 2004 when a park resident 


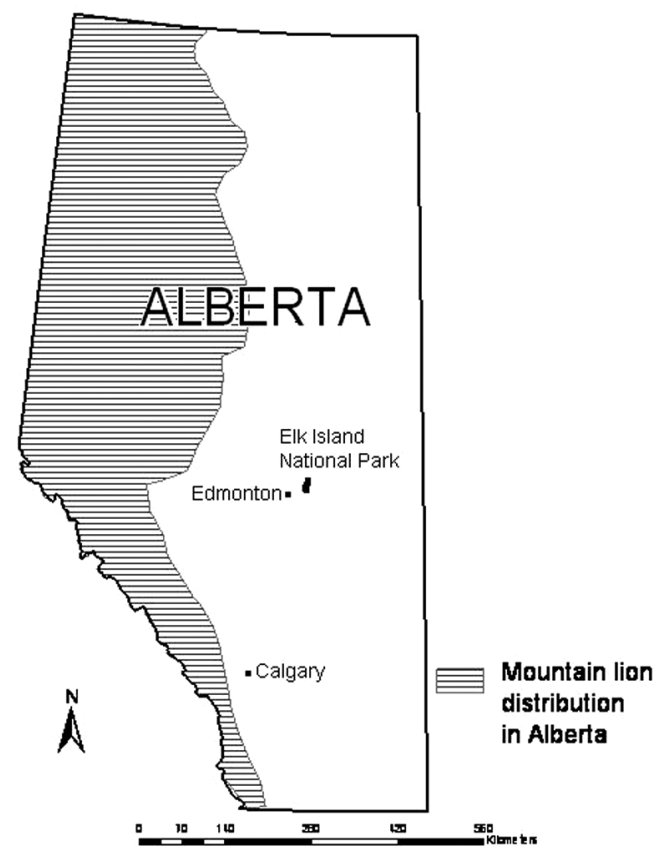

FIGURE 1. Location of Elk Island National Park in east-central Alberta. The shaded area indicates the distribution of Mountain Lion in Alberta (based on Pattie and Fisher 1999).

observed a Mountain Lion in the main part of the park (Figure 2). On two occasions, acreage owners on lands east and north of the park heard estrous calls of a Mountain Lion (October 2003 and August 2004). The landowner who reported the August 2004 calls observed a small Mountain Lion on his property a few days later.

In addition to sightings, four ungulate mortalities with wounds consistent with Mountain Lion predation (Ross et al. 1997) have been documented in the park since the winter of 2002-2003 (Figure 2). Prey species were: 2 American Elk (Cervus canadensis), 1 Moose (Alces alces), and 1 White-tailed Deer (Odocoileus virginianus). In all cases the carcasses had signs of wounds and fatal injuries to the neck and, in some cases, large puncture marks in the hide. Apart from Coyotes (Canis latrans), EINP lacks any large resident predators. In addition, the park has very high ungulate densities (approximately 13 ungulates per $\mathrm{km}^{2}$; Parks Canada unpublished data) and is home to American Elk, Moose, Bison (Bison bison), White-tailed Deer, and Mule Deer (Odocoileus hemionus). The park also has a large Beaver (Castor canadensis) population and many resident medium and small mammal species including porcupine (Erethizon dorsatum), Muskrat (Ondatra zibethicus) and Red Squirrel (Tamiasciurus hudsonicus). Hare (Lepus spp.) are at low densities in the park (Super 1951).

The park provides adequate undeveloped habitat and

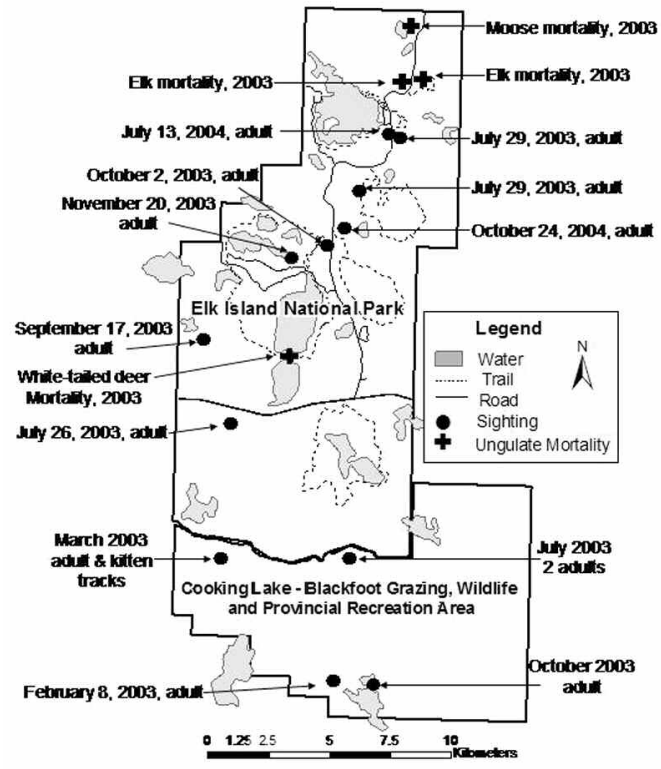

FIGURE 2. Mountain Lion sightings and wildlife mortalities consistent with predation by Mountain Lion in Elk Island National Park and the Cooking Lake - Blackfoot Grazing, Wildlife and Provincial Recreation Area since February 2003.

food resources to support an adult Mountain Lion (Spalding and Lesowski 1971; Ross and Jalkotzy 1992; Ross et al. 1997; Robinson et al. 2002). Currently, park staff translocate Bison and American Elk away from the park to reduce the impact of intense herbivory on vegetation. The presence of large predators, such as Mountain Lions, may help to reduce the ungulate densities in the park, and therefore moderate the amount of active management of ungulate populations by park staff.

The park is completely fenced and the abundance of prey species might offer enough resources to support a future Mountain Lion population. Given that successful reproduction in Mountain Lions is related to the availability of food (Pierce et al. 2000), the likely presence of a mated pair within EINP suggests such a scenario is not unrealistic.

\section{Acknowledgments}

We thank Conservation Officer Ed Whitelock and Park Warden Olaf Jensen for providing us with additional information on Mountain Lion sightings. We also thank three anonymous reviewers for their editorial comments.

\section{Documents Cited}

Burns, G. R., and N. L. Cool. 1984. A biophysical inventory of the non-ungulate mammals of Elk Island National Park. Report prepared for Parks Canada by the Canadian Wild- 
life Service, Edmonton, Alberta, Canada. 195 pages.

Soper, J. D. 1940. Preliminary final report on Elk Island National Park, Alberta, Canada. unpublished report. Department of Mines and Resources Lands, Parks and Forest Branch, National Parks Bureau. Edmonton, Alberta, Canada. 46 pages.

\section{Literature Cited}

Achuff, P. L. 1994. Natural regions, subregions and natural history themes of Alberta - a classification for protected areas management, revised and updated December 1994. Alberta Environmental Protection, Edmonton, Alberta, Canada. 72 pages.

Banfield, A. W. F. 1974. The mammals of Canada. University of Toronto Press, Toronto, Ontario, Canada. 438 pages.

Bird, R. D. 1961. Ecology of the aspen parkland of western Canada in relation to land use. Canada Department of Agriculture, Ottawa, Ontario, Canada. 155 pages.

Gau, R. J., R. Mulders, T. Lamb, and L. Gunn. 2001. Cougars (Puma concolor) in Northwest Territories and Wood Buffalo National Park. Arctic 54: 185-187.

Logan, K. A., and L. Sweanor. 1999. Puma. Pages 347-77 in Ecology and management of large mammals in North America. Edited by S. Demarais and P. R. Krausman Prentice-Hall, Englewood Cliffs, New Jersey.

Pattie, D., and C. Fisher. 1999. Mammals of Alberta. Lone Pine Publishing. Edmonton, Alberta, Canada. 240 pages.

Pierce, B. M., V. C. Bleich, and R. T. Bowyer. 2000. Social organization of Mountain Lions: does a land-tenure system regulate population size? Ecology 81: 1533-1543.
Robinson, H. S., R. B. Wielgus, and J. C. Gwilliam. 2002. Cougar predation and population growth of sympatric mule deer and white-tailed deer. Canadian Journal of Zoology 80: 556-568.

Ross, P. I., and M. G. Jalkotzy. 1992. Characteristics of a hunted population of cougars in southwestern Alberta. Journal of Wildlife Management 56: 417-426.

Ross, P. I., M. G. Jalkotzy, and B. M. Festa. 1997. Cougar predation on bighorn sheep in southwestern Alberta during winter. Canadian Journal of Zoology 75: 771-775.

Smith, H. C. 1979. Mammals of the Edmonton area. Provincial Museum of Alberta Natural History Occasional Paper Number 2. Queens Printer, Edmonton, Alberta, Canada. 34 pages.

Smith, H. C. 1993. Alberta mammals, an atlas and guide. The Provincial Museum of Alberta. Edmonton, Alberta, Canada. 238 pages.

Soper, J. D. 1951. The mammals of Elk Island National Park, Alberta Canada. Wildlife Management Bulletin Series 1, Number 3. Canadian Wildlife Service, Ottawa, Ontario, Canada. 27 pages.

Soper, J. D. 1964. The mammals of Alberta. The Hamley Press, Ltd. Edmonton, Alberta, Canada. 402 pages.

Spalding, D. J., and J. Lesowski. 1971. Winter food of the cougar in south-central British Columbia. Journal of Wildlife Management 35: 378-381.

Received 19 December 2003

Accepted 23 December 2004 